\title{
Biomarkers for early selection in eucalyptus tolerant to dieback associated with water deficit
}

\author{
Samyra Alves Condé ${ }^{1}$, Edgard Augusto de Toledo Picoli ${ }^{1} \oplus$, Thais Roseli Corrêa ${ }^{1} \oplus$, \\ Luiz Antônio dos Santos Dias ${ }^{1} \mathbb{0}$, Rodrigo Dal Sasso Lourenço ${ }^{1}{ }^{\circ}$, Francisco Charles dos Santos Silva ${ }^{1} \mathbb{0}$, \\ Washington Luiz Pereira ${ }^{2} \oplus$, Edival Angelo Valverde Zauza $^{3}{ }^{\oplus}$

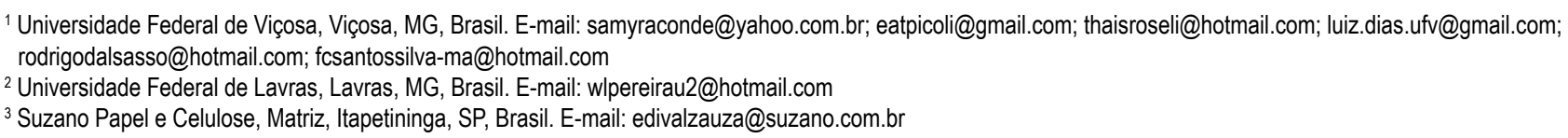

ABSTRACT: Water deficit causes a number of changes in plant development and physiology and is reported to be a trigger for eucalyptus dieback disorder. Dieback manifests itself in adult individuals, which hampers the selection of tolerant material and, therefore, means potential jeopardy to commercial plantings. Genetic parameters of phenotypic traits were estimated by the mixed model methodology (REML/BLUP), based on the observation of seedlings from twelve commercial eucalyptus clones grown under water stress. The water deficit was simulated by using polyethylene glycol (PEG 6000) and controlling the water depth administered to the plants for a period of 120 days. Among the evaluated anatomical and physiological characteristics, 10 biomarkers were selected for discriminating the clones, based on their differentiated and significant response among genotypes as well as relevant heritability and accuracy. The best-ranked clones demonstrated tolerance pattern in accordance to the empirical information in the production fields. Our results support the feasibility of early selection for selecting eucalyptus genotypes more tolerant to dieback and to water deficit.

Key words: forest breeding; genetic parameters; physiological disorder; plant anatomy; plant physiology; selection index; water deficit

\section{Biomarcadores para seleção precoce em eucaliptos tolerantes à seca de ponteiros associada ao déficit hídrico}

RESUMO: O déficit hídrico causa uma série de alterações no desenvolvimento e fisiologia das plantas além de ser relatado como um gatilho para o distúrbio de seca de ponteiros em eucalipto. A seca de ponteiros se manifesta em idade adulta, o que dificulta a seleção de material tolerante ao distúrbio e, portanto, com potencial comprometimento dos plantios comerciais. Os parâmetros genéticos de características fenotípicas foram estimados pela metodologia de modelos mistos (REML/BLUP) a partir de mudas de doze clones comerciais de eucalipto conduzidos sob estresse hídrico. 0 déficit hídrico foi simulado com 0 uso de polietilenoglicol (PEG 6000) e com o controle da lâmina de água administrada às plantas por um período de 120 dias. Dentre as características anatômicas e fisiológicas avaliadas, foram selecionados 10 biomarcadores para a discriminação dos clones, com base em sua resposta diferenciada e significativa entre os genótipos, bem como herdabilidade e acurácia relevantes. Os clones melhor ranqueados apresentaram padrão de tolerância em acordo com as informações empíricas nos campos de produção. Nossos resultados dão suporte à viabilidade da seleção precoce para seleção de genótipos de eucalipto mais tolerantes à seca de ponteiros e ao déficit hídrico.

Palavras-chave: melhoramento florestal; parâmetros genéticos; distúrbio fisiológico; anatomia vegetal; fisiologia vegetal; índice de seleção; déficit hídrico 


\section{Introduction}

Eucalyptus plantations in Australia, North America, Europe (Jurskis, 2005) and Brazil (Mattiello et al., 2009) have been affected by "dieback", a physiological disorder characterized by the drying tips of twigs and branches from the main stem and by the incidence of lesions or small cankers in the same parts. These lesions rapidly evolve and the complete defoliation occurs under more severe conditions, culminating in death of the branch apical part, with the consequent impairment of the plant growth (Ferreira, 1989; Leite et al., 2014).

Dieback is considered a disease of complex etiology, induced by abiotic and biotic factors. Among the abiotic factors, the water deficit (Jurskis, 2005; Corrêa et al., 2017) is considered an intensifier of this disorder and one of the main environmental factors that limits the growth and yield of agricultural crops (Chaves et al., 2009). The impact of water deficit on vegetables is complex, since plants have different adaptive mechanisms to water scarcity, such as, for example, the reduction of water potential combined with morphological, physiological and anatomical adaptations.

Introducing genotypes adapted to water-stress conditions and tolerant to physiological disturbances such as dieback is essential for maintaining the productive potential of the sector, with this as one of the spearheading objectives of forest genetic improvement or breeding. However, eucalyptus breeding has a long cycle and high assessment costs for obtaining superior clones (Beltrame et al., 2012). With this in mind, the early selection contributes in reducing the crop cycle, increasing yield and optimizing the planting areas, since the traits evaluated in younger plants are used as predictors of characteristics during their productive adult stage, thus anticipating the genetic gains (Moraes et al., 2014).

In order to assist the breeder in selecting superior clones for various environmental conditions, estimates of genetic parameters are of great use during the designing of breeding programs (Miranda et al., 2013). Another important factor in these programs is the employment of phenotypic biomarkers, known as descriptors. Biomarkers are defined as any elements that can differentiate and characterize an individual. These said characteristics used in the selection must be reproduced in the resulting offspring (Oliveira et al., 2007) and are necessary requirements for reducing the selection time of superior clones for the formation of commercial plantations.

Selection techniques play a fundamental role in the perennial plants breeding, when striving for superior genotypes in the desirable characteristics. Hence, using the selection index can be an effective alternative, which permits evaluating and ordering the candidates for selection with regards to the objective character aimed at the breeding (Resende \& Barbosa, 2005).

Based on the experimental data from early evaluation in commercial eucalyptus clones, our study was conducted with the following objectives: i) identifying and validating anatomical and physiological biomarkers for early selection, aiming at tolerance to water stress and dieback, by means of estimating genetic parameters; and ii) validating the early selection and classification of clones regarding their tolerance to water deficit and dieback.

\section{Materials and Methods}

The experiment was conducted in a greenhouse at the Clonar: Plant Disease Resistance company, located in Cajuri, MG (latitude $20^{\circ} 47^{\prime} 26^{\prime \prime} \mathrm{S}$ and longitude $42^{\circ} 47^{\prime} 48^{\prime \prime}$ W), using seedlings from twelve commercial clones (Table 1), provided by the Suzano Papel e Celulose company. The choice of these clones was based on their availability and response divergence regarding the tolerance to dieback and to water deficit, as according to field observations. Suzano Papel e Celulose provided the field data on the degree of tolerance to dieback and to the water deficit of each used clone, according to the history survey in the production areas most prone to this disturbance occurring.

The 100-days seedlings were transplanted into black plastic bags with capacity for $2 \mathrm{~L}$ containing the substrate Carolina Soil (70\% Sphagnum, 20\% charred rice husk, 10\% perlite) enriched with superphosphate $\left(6.0 \mathrm{~kg} \mathrm{~m}^{-3}\right)$. Afterwards, they went under acclimatization in a greenhouse, at mean temperature of $25 \stackrel{\circ}{\circ}$, mean relative humidity of $70 \%$, with natural lighting and daily irrigation (control). The experiment was set up after 40 days of acclimatization. Cultural treatments were performed as according to the standard nursery practices of Clonar, including initial and top-dressing fertilizations, daily irrigation and phytosanitary control when necessary.

The experiment was set up and conducted in a randomized block design with three replicates. Originally, clones from other companies were also used in other analyzes, while the set of anatomical and physiological evaluations and analyzes were performed only for the Suzano clones, considering a 12 $x 3$ factorial design, with 12 clones (Table 1 ) and 3 treatments, totaling 118 evaluated plants.

Table 1. Relation of the commercial eucalyptus clones and their classification regarding the tolerance and susceptibility to dieback and water deficit, based on empirical data from the production areas.

\begin{tabular}{cccc}
\hline Clone & Species or hybrid & Dieback & $\begin{array}{c}\text { Water } \\
\text { deficit }\end{array}$ \\
\hline C1 & E. grandis $\times$ E. urophylla & Tolerant & Tolerant \\
C2 & E. grandis $\times$ E. pellita & Tolerant & Tolerant \\
C3 & E. grandis $\times$ E. urophylla & Tolerant & Tolerant \\
C4 & E. grandis $\times$ E. pellita & Susceptive & Susceptive \\
C5 & E. grandis $\times$ E. urophylla & Susceptive & Susceptive \\
C6 & E. platyphylla & Tolerant & Tolerant \\
C7 & E. grandis $\times$ E. urophylla & Tolerant & Tolerant \\
C8 & E. grandis $\times$ E. urophylla & Susceptive & Susceptive \\
C9 & E. grandis & Tolerant & Tolerant \\
C10 & E. urophylla & Tolerant & Tolerant \\
C11 & E. grandis & Susceptive & Susceptive \\
C12 & E. grandis $x$ E. urophylla & Tolerant & Tolerant \\
\hline
\end{tabular}

Source: Suzano Papel e Celulose. 
Treatments used for simulating the water deficit were established and conducted as according to Corrêa et al. (2017): (1) control - plants kept in a greenhouse, at a mean temperature of $25 \stackrel{\circ}{ } \mathrm{C}$, illuminated with natural light, $70 \%$ of relative humidity and daily irrigation of $260 \mathrm{ml}$ distributed in two 10-minute applications of $130 \mathrm{ml}$ (9:30h - 14:30h) through an automated micro-sprinkler system set up in elevation with a spacing of $2.0 \mathrm{~m} \times 3.2 \mathrm{~m}$ and a nominal flow rate of 160L/h per emitter; (2) $100 \mathrm{H}_{2} \mathrm{O}$ - standard procedure for simulating water stress during all days of the experiment, with irrigation restricted to applying $100 \mathrm{~mL}$ of water per pot; and (3) 300PEG - Standard procedure for simulating water stress every two days during all experiment, by applying $100 \mathrm{~mL}$ of polyethylene glycol solution 6000 (PEG), at the concentration of $300 \mathrm{~g} \mathrm{~L}^{-1}$ per pot.

Plant material was collected after the acclimatization period, with PEG application at intervals of 2 days, while keeping up the irrigation and the different water availability for the seedlings in the other treatments. The experiment duration lasted 17 weeks, approximately.

\section{Anatomical variables}

For the anatomical evaluation, samples of the petiole and leaf blade (middle third) of fully-expanded and healthy leaves were taken from the seedlings middle third. As for the anatomical analysis of the petiole, we evaluated its crosssectional area (CSAP); the vascular tissue (VTA); xylem (XYL); phloem (PHL); and the cortex (CA). For evaluating the leaf blade, we evaluated the variables of total leaf thickness (TLT); adaxial-face epidermis (AFE); palisade parenchyma (PP); lacunous parenchyma (LP); and abaxial-face epidermis (BFE).

The samples from the leaf blade and petiole were fixed in FAA $_{50}$ (formaldehyde, acetic acid and ethyl alcohol 50\%, in the 5:5:90 proportion, (v:v:v)), for $48 \mathrm{~h}$ and stored afterwards in $70 \%$ ethanol. The material was subsampled and sections of 0.5 $\mathrm{cm}^{2}$ from the median portion of the limbus (50\% of its length) and $0.5 \mathrm{~cm}$ from the petioles section were taken at $50 \%$ of the length of its total. The samples were thus dehydrated in the sequence of $85 \%$ and $95 \%$ ethanol, kept for $2 \mathrm{~h}$ in each one. Later, they were subjected to a mixture of $95 \%$ ethanol and pure resin (Historesin Leica, prepared according to the manufacturer instructions), in the proportion of $1 \mathrm{v}: 1 \mathrm{v}$, for $48 \mathrm{~h}$.

The infiltration was with pure resin, in a desiccator subjected to vacuum, at intervals of $12 \mathrm{~h}$ each, during a period of 7 days. The pure resin was mixed with the polymerizer, according to the manufacturer instructions, and the samples were stacked into plastic molds. Then, these molds were kept for 72 hours in an oven at $35^{\circ} \mathrm{C}$ and were finally fixed in wooden blocks with the Super Bonder ${ }^{\circ}$ universal adhesive. Cross sections with $5 \mu \mathrm{m}$ thickness were obtained in an automatic rotary microtome (RM2155, Leica Microsystems Inc., USA) with glass knives. The sections cut were allocated to a container with hot water, adhered to histological slides, stained with $0.05 \%$ toluidine blue, $\mathrm{pH}$
6.5 and assembled with synthetic resin (Permount, Fisher Scientific, USA).

The images were obtained by a digital camera (AxioCam HRc, Zeiss, Germany) and a microcomputer with an imagecapture program (Axio Vision, Zeiss, Germany), coupled to a light microscope (AX-70 TRF, Olympus Optical, Japan). The photos were software-analyzed with the Image Pro Plus image-analysis software (MediaCybernetics), with five fields per repetition measured for each analyzed variable, and, thus, the mean was obtained.

Stomatal density (SD) was performed based on the printing method of epidermis. During the penultimate week of the experiment, three healthy and expanded leaves, located in the middle third of the canopy of each genotype-treatment combination, had their central rib portion removed. Samples with these leaves upper and lower faces were assembled on histological slides with a drop of Super Bonder ${ }^{\circledR}$ universal adhesive for obtaining the epidermal impression, as described by Segatto et al. (2004). Approximately $10 \mathrm{~s}$ after application, the leaf was removed and the slide properly identified. Stomatal analysis and quantification were performed by using the Image Pro Plus program.

All analyzes were held at the Plant Anatomy Laboratory at the Federal University of Viçosa.

\section{Physiologic variables}

The plants water status was evaluated based on the leaf water potential, measured with a pressure chamber model Scholander Molelo 1000 (PMS Instrument Company) in two different moments: in the eighth and tenth week. Measurements were taken on the third fully-expanded and healthy leaf, counted from the plant apex, in two periods, from $3 \mathrm{~h}: 00$ to $5 \mathrm{~h}: 00$ and from 13h:00 to $15 \mathrm{~h}: 00$ (minimum potential), in three replicates per treatment.

Transpiration variables (E1 and E2), stomatal conductance (gs), photosynthesis (A1 and A2), water use instant efficiency $(A / E)$, intrinsic water use efficiency (A/gs) and internal carbon/ external carbon ratio ( $\mathrm{Ci} / \mathrm{Ca}$ ) were all measured aided by a IRGA device (LCpro-SD, ADC Biocientific Ltd.) and evaluated at 60 and 90 days during the experiment, using expanded leaves from the middle third of the plants.

\section{Statistical analysis}

Estimates of the genetic parameters were obtained by the mixed model methodology, the REML/BLUP procedure (Maximum Restricted Likelihood/Best Unbiased Linear Prediction) and the analysis of deviance (Anadev) (Resende \& Duarte, 2007), following the subsequent model:

$$
\mathrm{y}=\mathrm{Xb}+\mathrm{Zg}+\mathrm{e}
$$

in which:

$y, b, g$, e: data vectors, fixed effects (general mean, repetitions and treatments), total genotypic effects (random) and random errors, respectively.

$\mathrm{X}$ and $\mathrm{Z}$ : incidence matrixes for $\mathrm{b}$ and $\mathrm{g}$, respectively. 
Equations of the Mixed Model:

$$
\left[\begin{array}{cc}
X^{\prime} X & X^{\prime} Z \\
Z^{\prime} X & Z^{\prime} Z+A^{-1}\left(\left(1-h^{2}\right) / h^{2}\right)
\end{array}\right]\left[\begin{array}{l}
\hat{b} \\
\hat{g}
\end{array}\right]=\left[\begin{array}{l}
X^{\prime} y \\
Z^{\prime} y
\end{array}\right]
$$

$\mathrm{h}^{2}=\frac{\hat{\sigma}_{\mathrm{g}}^{2}}{\left(\hat{\sigma}_{\mathrm{g}}^{2}+\hat{\sigma}_{\mathrm{e}}^{2}\right)}$ : individual heritability in a wide sense.

Estimates of the Variance Components via EM Algorithm

$$
\begin{gathered}
\hat{\sigma}_{\mathrm{e}}^{2}=\frac{\left[\mathrm{y}^{\prime} \mathrm{y}-\hat{\mathrm{b}}^{\prime} X^{\prime} \mathrm{y}-\hat{\mathrm{g}}^{\prime} \mathrm{Z}^{\prime} \mathrm{y}\right]}{[\mathrm{N}-\mathrm{r}(\mathrm{X})]} \\
\hat{\sigma}_{\mathrm{g}}^{2}=\frac{\left[\hat{\mathrm{g}}^{\prime} \mathrm{A}^{-1} \hat{\mathrm{g}}+\sigma_{\mathrm{e}}^{2} \operatorname{tr} \mathrm{C}^{22}\right]}{\left[\mathrm{N}_{\mathrm{g}}\right]}
\end{gathered}
$$

in which:

$r(X)$ - rank or number of linearly independent columns of $X$. $\mathrm{C}^{22}$ - is of the form

$$
\left[\begin{array}{cc}
C^{11} & C^{12} \\
C^{21} & C^{22}
\end{array}\right]=\left[\begin{array}{cc}
X^{\prime} X & X^{\prime} Z \\
Z^{\prime} X & Z^{\prime} Z+A^{-1}\left(\frac{\sigma_{e}^{2}}{\sigma_{g}^{2}}\right)
\end{array}\right]^{-1}
$$

$\mathrm{N}_{\mathrm{g}}$ - number or random elements (individuals).

A - matrix of additive genetic parenthood.

tr - matrix trace operator, given by the sum of the diagonal elements of the matrix.

$\mathrm{N} \quad$ - total data number.

Predicted genotypic values were used to calculate the selection index, based on the ranks mean (Mulamba \& Mock, 1978). The Selegen-Reml/Blup software, version 2014 (Resende, 2016) was used for carrying the statistical analyzes out.

\section{Results and Discussion}

The joint evaluation of anatomical and physiological characteristics is a necessary approach in the studies related to responses and adaptation strategies to abiotic stresses, contributing to the understanding of the tolerance mechanisms. Significant changes in the physiological processes are expected concomitantly with the anatomical changes, as an attempt by the individuals in adapting to the stress condition. This is of particular relevance when considering the pedigree of the used genotypes, four eucalyptus species (Table 1), which can have different adaptation strategies that, altogether, can provide a greater or lesser degree of water stress tolerance the genotypes.
Among the 24 anatomical and physiological characteristics evaluated, 11 had medium heritability and high accuracy (greater than 70\%) (Table 2) as according to Resende \& Duarte (2007). The heritability estimates demonstrated considerable genetic control for these 11 characteristics, and this is the criterion for classifying them as phenotypic biomarkers for early selection of eucalyptus clones tolerant to water deficit and dieback.

The results of the Analysis of Deviance illustrated in Table 3 are in accordance with the significance of all evaluated variables in this experiment and demonstrate the importance of the variables selected as biomarkers for early selection of eucalyptus clones tolerant to dieback and water deficit.

Plant anatomy is fundamental in the understanding of the plant adaptations mechanisms, since, when under stress, anatomical change is one way of adapting to the new conditions (Taiz \& Zeiger, 2013). For estimating the stomatal density, the stomata counting was performed only on the leaves abaxial surface, since the studied clones are hypoestomatic. Stomatal density showed heritability of medium magnitude and of $80 \%$ accuracy (Table 2). According to Resende \& Duarte (2007), these parameters values are from medium to high, for a woody species like the eucalyptus.

In particular, the stomatal density demonstrated a qualitatively significant difference between tolerant and susceptible clones, with it higher in clones susceptible to dieback and to water deficit and lower in tolerant clones, as well as the stomatal density (Figure 1).

Under adverse environmental conditions such as water stress, the stoma density is reduced, which was considered as a strategy to regulate the water loss during the water deficiency, reducing stomatal conductance and transpiration (Silva et al., 2009; Doheny-Adams et al., 2012; Hamanishi et al.,

Table 2. Estimates of the variance components $\left(\mathrm{h}^{2} \mathrm{~g}\right.$ Heritability; Acgen - Heritability accuracy; Cve\% - experimental variation coefficient) for the anatomical variables of stomatal density (SD), petiole cross-sectional area (CSAP), vascular tissue cross-sectional area (VTA), xylem cross-sectional area $(\mathrm{XYL})$, phloem cross-sectional area (PHL), cortex crosssectional area (CA) and total leaf thickness (TLT); and for

\begin{tabular}{|c|c|c|c|c|}
\hline \multicolumn{5}{|c|}{ Genetic parameters estimates } \\
\hline Variables & $h^{2} g$ & Acgen & Cve\% & Mean \\
\hline Stomatal density & 0.22 & 0.80 & 16.87 & 122.25 \\
\hline Petiole cross-sectional area & 0.30 & 0.89 & 20.98 & 529.39 \\
\hline Vascular tissue cross-sectional area & 0.36 & 0.91 & 23.73 & 121.22 \\
\hline Xylem cross-sectional area & 0.28 & 0.87 & 28.17 & 49.39 \\
\hline Phloem cross-sectional area & 0.34 & 0.89 & 23.50 & 71.83 \\
\hline Cortex cross-sectional area & 0.27 & 0.87 & 21.15 & 408.16 \\
\hline Total leaf thickness & 0.14 & 0.77 & 16.08 & 152.20 \\
\hline Stomatal conductance & 0.11 & 0.70 & 87.00 & 0.11 \\
\hline Transpiration 60 & 0.14 & 0.75 & 50.01 & 2.06 \\
\hline Photosynthesis 90 & 0.12 & 0.74 & 41.67 & 6.78 \\
\hline Transpiration 90 & 0.10 & 0.71 & 44.60 & 2.70 \\
\hline
\end{tabular}
the physiological variables : stomatal conductance (gs), transpiration 60 days (E1), photosynthesis 90 days (A2) and transpiration 90 days (E2). 
Table 3. Analysis of Deviance for the anatomical, physiological, morphological and nutritional variables evaluated in 12 divergent commercial eucalyptus clones regarding the tolerance to dieback and to water deficit. Evaluation performed with data from the three treatments (Control, $100 \mathrm{H}_{2} \mathrm{O}$ and 300PEG).

\begin{tabular}{|c|c|c|c|}
\hline Variable & Effect & Deviance & LRT \\
\hline \multirow{2}{*}{ Stomatal density } & Clones & 756.42 & $4.16^{* *}$ \\
\hline & Complet & 752.26 & \\
\hline \multirow{2}{*}{$\begin{array}{l}\text { Petiole cross-sectional } \\
\text { area }\end{array}$} & Clones & 1083.34 & $10.44^{* * *}$ \\
\hline & Comple & 1072.9 & \\
\hline \multirow{2}{*}{$\begin{array}{l}\text { Vascular tissue } \\
\text { cross-sectional area }\end{array}$} & Clones & 821.41 & $12.69 * *$ \\
\hline & Complete Model & 808.72 & \\
\hline \multirow{2}{*}{ Xylem cross-sectional area } & Clones & 671.27 & $8.78 * * *$ \\
\hline & Complete Model & 662.49 & \\
\hline \multirow{2}{*}{ Phloem cross-sectional area } & Clones & 718.23 & $14.89 * *$ \\
\hline & Comple & 703.34 & \\
\hline \multirow{2}{*}{ Cortex cross-sectional area } & Clones & 103 & $8.37 * * *$ \\
\hline & Complete Model & 1022.15 & \\
\hline \multirow{2}{*}{ Total leaf thickness } & Clones & 769.47 & $3.84 * *$ \\
\hline & Comple & 765.63 & \\
\hline \multirow{2}{*}{ Stomatal conductance } & Clones & 324.24 & $1.84^{*}$ \\
\hline & Complet & 322.40 & \\
\hline \multirow{2}{*}{ Transpiration 60} & Clones & 148.38 & $2.65^{*}$ \\
\hline & Complet & 145.73 & \\
\hline \multirow{2}{*}{ Photosynthesis 90} & Clones & 399.74 & $63.57^{* * *}$ \\
\hline & Comple & 336.17 & \\
\hline \multirow{2}{*}{ Transpiration 90} & Clones & 169.86 & $2.9^{*}$ \\
\hline & Complete Model & 166.96 & \\
\hline
\end{tabular}

Tabulated chi-square: $2.71 ; 3.84$ and 6.63 for the significant levels of 10,5 and $1 \%$, respectively.

2012). Grisi et al. (2008) observed in their study a difference between stomatal density and irrigated and non-irrigated treatments for two coffee cultivars; however, for 'Catuaí', the highest stomata number was in the irrigated treatment while 'Siriema' was in the non-irrigated one (Figure 6A).

Despite the similarity in the organization of the epidermal surface of eucalyptus leaves (Figure 1), the quantitative analysis of the stomatal density data is an important biomarker for discriminating divergent genotypes for tolerance to dieback and to water deficit.

The same directive is valid for the anatomical section cuts of the petiole cross-section area, from tolerant and susceptible clones (Figure 2). Verifying the differences between the clones was mediated by the quantitative analysis of the areas from the respective tissues that compose the petioles. The following anatomical variables of the petiole: total cross-sectional area (CSA); cross-sectional areas of the vascular tissue (VTA); the xylem (XYL); phloem (PHL) and cortex (CA) all showed heritability estimates between 0.22 and 0.36 , which are classified as medium or moderate $0.15<$ $h^{2} \mathrm{~g}<0.50$ ) (Table 2). These limits of variation and heritability classification are in accordance with the scale proposed by Resende \& Duarte (2007).

The petiole cross-sectional area variable showed moderate heritability and high accuracy. Plants under some type of stress tend to inhibit the expansion of cells in the cortex, parenchyma, pericycle and cambium, thus reducing
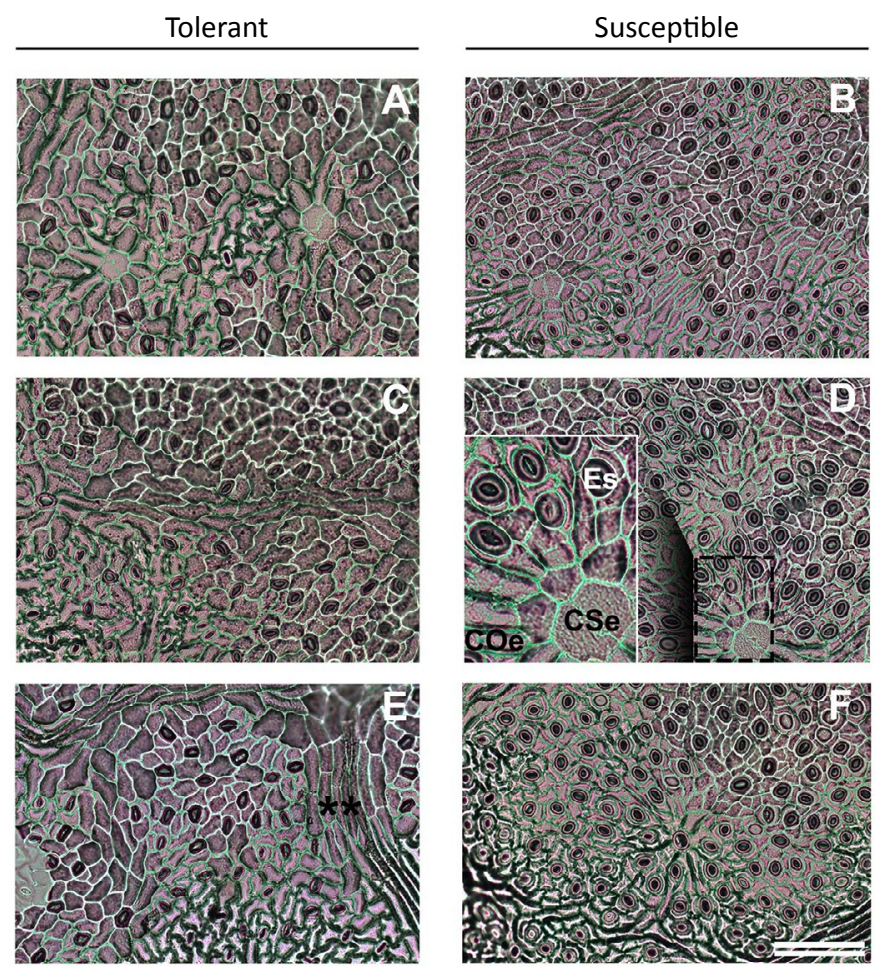

Figure 1. Details of the epidermis faces from eucalyptus leaves to estimate stomatal density. A (C1), C (C6) and E (C9): genotypes tolerant to dieback and to water deficit; $B(C 4)$, $D(C 8)$ and $F(C 11)$ : susceptible genotypes. A and B: control treatments; C and D: 300 PEG treatment, and E and F: $100 \mathrm{H}_{2} \mathrm{O}$ treatment. ${ }^{* *}$ ordinary epidermal cells over vascular bundles; Es - stomata, COe - ordinary epidermal cell, CSe - epidermal cells over the secretory cavities. Bar $=100 \mu \mathrm{m}$ for all mages.

the number of cells in all tissues. Laajimi et al. (2011) reported that the water stress level differently affected the tissues in the petiole of adult plants of apricot (Prunus armeniaca L.), with a reduction of $11.4 \%$ in the spongy parenchyma and from 14.4 to $30.5 \%$ of the sclerenchyma, xylem and cambium with 0 and $50 \%$ of irrigation, respectively.

The cortex area variable demonstrated moderate heritability and $87 \%$ accuracy (Resende \& Duarte, 2007), with an evident reduction in the cortex region in the tolerant clones under stress conditions. The decrease in cortex thickness in plants subjected to water deficiency may favor less water loss, similar to what occurs in roots grown under the water deficit, where a reduction in the cortical region was also observed (Huck et al., 1970).

The xylem area was yet another variable that had heritability of 0.28 and $87 \%$ accuracy. Dayer et al. (2017) observed in their study with petioles from grapevine leaves, under water-deficit conditions, development of the minor xylem area when compared to grapevines with no water restriction. These results suggest that the reduction in hydraulic conductivity not only can be brought about by cavitation of the xylem, but also by the reduction in its area size.

The phloem area in the petiole variable had moderate heritability and high accuracy. Under water-deficit conditions, 

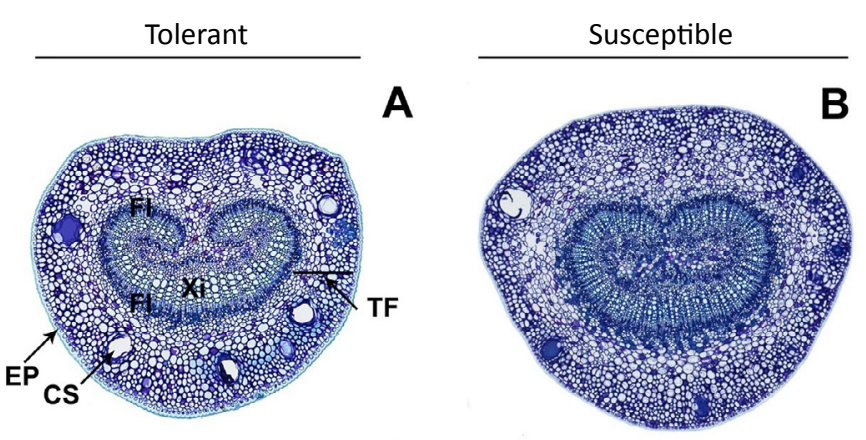

C
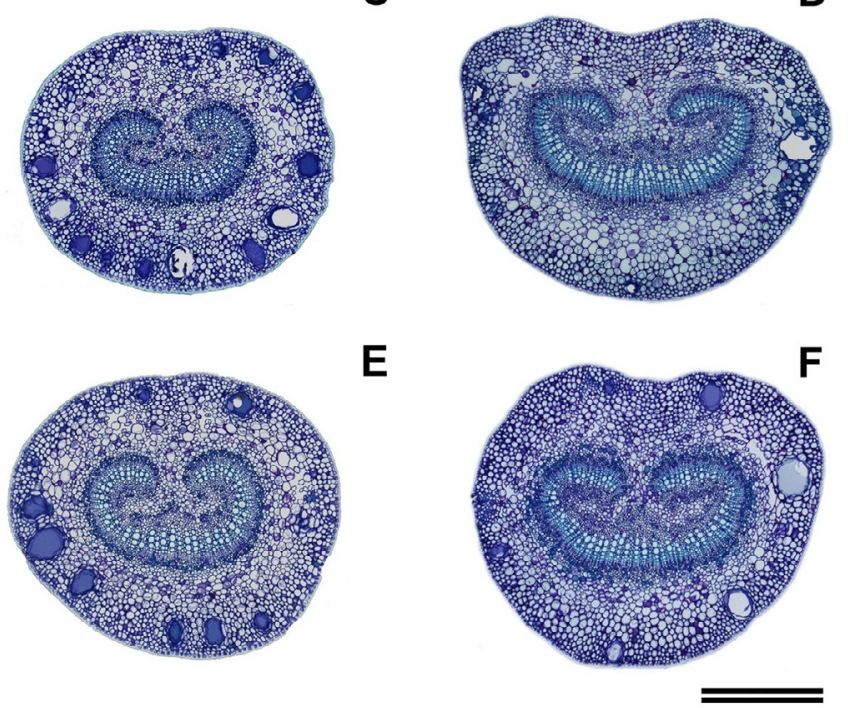

Figure 2 . Cross sections of petioles from eucalyptus. A (C1), $C$ (C6) and $E$ (C9): genotypes tolerant to dieback and to water deficit; B (C4), D (C8) and F (C11): susceptible genotypes. A and $\mathrm{B}$ : control treatments; $\mathrm{C}$ and $\mathrm{D}$ : 300 PEG treatment, and $\mathrm{E}$ and F: $100 \mathrm{H}_{2} \mathrm{O}$ treatment. $\mathrm{FI}$ - phloem, $\mathrm{Xi}$ - xylem, TF - fundamental tissue, CS - secretory cavity, EP - epidermis. Bar $=100 \mu \mathrm{m}$ for all images

the sap conduction by the phloem is affected in a way that some plant tissues suffer a reduction in their carbon reserves, which may even, under extreme conditions, lead the plant to its death (Sala et al., 2010).

Despite the diversity of the transport-related factors in the xylem and phloem, the proportion of the total vascular tissues in the petiole had heritability and accuracy of 0.36 and 91\%, respectively. For Alves \& Angyalossy-Alfonso (2000), environmental factors alter the dimensions and arrangement of the vascular elements positively, attempting to ensure the increased transport safety when the plant is prone to any type of stress.

Kulkarni \& Deshpande (2006) observed in tomatoes that petiole characteristics such as total thickness and length of elements from xylem and phloem are important for the tomato genotypes tolerant to water deficit. The investment in less-favorable characteristics to the xylem cavitation in petioles was a relevant factor in discriminating genotypes of the genus Hevea tolerant to water deficit (Jinagool et al., 2015). The water stress adapting ability was also highlighted by Laajimi et al. (2011), who observed the thickness variation in the petiole tissues of Prunus in response to the moderate and severe water stresses.

Despite verifying that investment in vascular tissues is relevant to the tolerance, a greater detail of the xylem cell composition has a significant contribution to the tolerance to water deficit. There is a cost and benefit relation of the efficiency and safety of vessel elements that is established during the differentiation of tracheal elements: the greater the element volume, the greater the cavitation risk under water stress conditions (Jacobsen et al., 2019), even though more sap is transported.

Additionally, the organization of the vessel system (Jacobsen et al., 2019) and other cellular components of the xylem (Barotto et al., 2016) are important for comprehending the transport in the xylem. Eucalyptus species with a higher proportion of vasicentric tracheids were less vulnerable to cavitation, while positive relations between the pressure for $12 \%$ loss of conductivity and the axial parenchyma percentage are in accordance with a role of the parenchyma in repairing embolisms (Barotto et al., 2016). These results illustrate the importance of a thorough evaluation of the vascular tissues, in particular and more easily-applied to the xylem; however, these elements metioned were not evaluated in the present study and should be properly addressed on another opportunity. Choosing variables to integrate a set used in the selection must meet the significance criteria for the evaluated genotypes, contribution to the tolerance characteristic as well as the easy access for a large sample number.

It is noteworthy that, as observed in the present report, estimates of the vascular and fundamental tissues proportions in the petiole region were relevant for discriminating genotypes more and less tolerant to dieback and to water deficit. The detailed study of these tissues and regions delimited by them can contribute to the comprehension of the mechanisms that support the tolerance phenotype.

Figure 3 illustrates the leaf blade anatomical sections cut from the tolerant and susceptible clones. The organization of tissues in the mesophyll, qualitative evaluation, was similar among the clones, from which, only by means of histometry, quantitative analysis, of the Cross-sectional areas of the regions/tissues, differences were found between the tolerant and susceptible clones. This difference was proved through measuring the evaluated areas.

From the leaf blade, only the variable of total leaf thickness had mean heritability and $77 \%$ accuracy, reducing its area for tolerant clones under water deficit. Due to this water deficiency, a thickness reduction in the mesophyll and leaf blade occurs, which may be due to a reduction in the cell strata number or in the intercellular spaces (Chartzoulakis et al., 2002). The tissues organization in the mesophyll can contribute to the tolerance to water deficit, since, with the intercellular spaces reduction, there are a greater compaction of the mesophyll and the increased internal resistance to the water vapor movement, thus reducing the evapotranspiration (Kutlu et al., 2009). Water stress was also reported as the promoter of the change in the tissues thickness from the leaf blade of Prunus (Laajimi et al., 2011). 
Tolerant

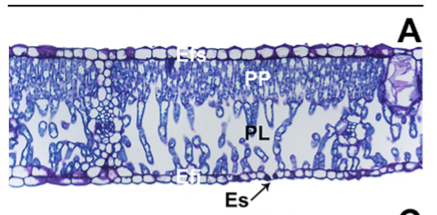

C
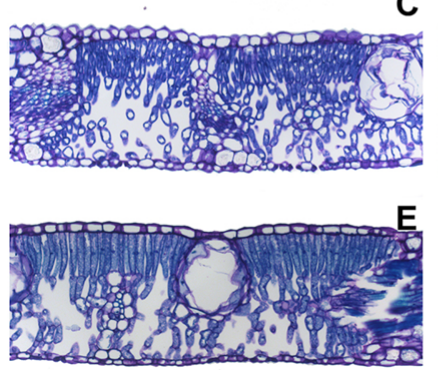

Susceptible

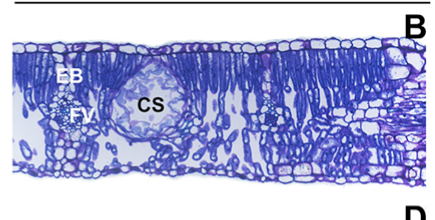

D
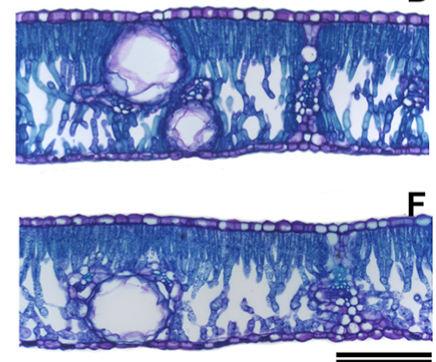

Figure 3. Cross sections of the leaves from commercial eucalyptus clones. A (C1), C (C6) and E (C9): genotypes tolerant to dieback and to water deficit; $B(C 4), D(C 8)$ and $F$ (C11): susceptible genotypes. A and B: control treatments; $C$ and D: 300 PEG treatment, and E and F: $100 \mathrm{H}_{2} \mathrm{O}$ treatment. Efs - upper-face epidermis, PP - palisade chlorophyll parenchyma, PL - lacunous chlorophyll parenchyma, Efi - lower-face epidermis, Es - stomata, EB - sheath extension, FV - vascular bundle, CS - secretory cavity. Bar $=100 \mu \mathrm{m}$ for all images.

The following physiological variables: stomatal conductance (gs), transpiration 60 days (E1), photosynthesis 90 days (A2) and transpiration 90 days (E2) had heritability between 0.10 and 0.14 , classified as of low magnitude $(0.01<$ $\left.\mathrm{h}^{2} \mathrm{~g}<0.15\right)$ according to Resende \& Duarte (2007). Contrarily, they all showed high accuracy (CAgen $>0.70$ ), according to the same authors.

According to Flexas et al. (2012), in a soil with waterrestriction conditions, tobacco plants reduce the water loss by decreasing stomatal conductance. This reduction leads to a lower $\mathrm{CO}_{2}$ influx into the chloroplasts, thus reducing the photosynthetic rate. These results reinforce the idea that stomatal conductance and photosynthesis are viable biomarkers for evaluating the level of tolerance to water deficit in plants, as they can measure different responses that in turn support the greater tolerance of some clones to the stress.

In relation to stomatal conductance, the evaluated transpiration at 60 and 90 days demonstrated a low heritability, but high accuracy (Table 2). For Resende (2002), if the heritability of a characteristic is $>0.50$, there is practically no advantage in using the family information, as the selection based only on individual information already provides a high accuracy $(>0.70)$, such is the case of the characteristics evaluated during this study, where the information comes directly from the clones, and not from the families, with this emphasizing the importance of working with more elaborated selection methods in future experiments. These variables are also subject to the influence of abiotic factors, which alter the water vapor gradient between the leaf surface and its surrounding air, the air humidity and temperature, the wind and the water availability of the soil.
In a study evaluating five eucalyptus clones, during five successive drought cycles, Chaves et al. (2004) verified that, in the first evaluated drought cycle, fully-irrigated plants had greater transpiration when compared to those under water deficiency. Transpiration is directly related to the stomatal density, and both proved to be good biomarkers for tolerance to dieback and water deficit, contributing to the reduction of transpiration and the number of stomata among the tolerant clones, also demonstrating significant accuracy and heritability in the present study.

Photosynthesis was significant only 90 days after conducting the experiment, showing 0.12 heritability and 74\% accuracy. The reduction in the photosynthetic rate is associated with the stomatal closure and, therefore, a reduction in the $\mathrm{CO}_{2}$ available within the leaf for photosynthesis (Larcher, 2006). Overall, the water deficit results in decreased photosynthesis, which is probably due to the partial closure of stomata (Tatagiba et al., 2009; Otto et al., 2013). In severe water-deficit conditions, photosynthetic rates decrease due to the inhibition of specific metabolic processes such as, for example, the photophosphorylation reduction in the Rubisco activity and other enzymes involved in the Calvin cycle and the RuBP-regenerating ability (Taiz \& Zeiger, 2013). For E. grandis, Hu et al. (2012) observed that from the sixth day with no irrigation onwards, the photosynthesis and stomatal conductance dramatically decreased to almost zero on the ninth day. Thus proving the direct relation between these two biomarkers found in this study.

Anatomical and physiological variables varied significantly between the tolerant clones and those susceptible to dieback and to water deficit. This variation was used in order to rank the clones according to their tolerance to stress or disturbance (Table 4). The ranking based on the mean rank index from Mulamba \& Mock (1978) was performed based on the variables that had heritability from low to high magnitude and high accuracy, in the water stress treatments (Table 4).

The classification of clones according to their tolerance to dieback and to water deficit was only based on the $100 \mathrm{~mL}$ $\mathrm{H}_{2} \mathrm{O}$ and $300 \mathrm{mg} \mathrm{L}^{-1}$ PEG treatments (Table 4).

Twelve clones were ordered by evaluating 24 characteristics and then ranking the genotypes. The classification of clones as tolerant to dieback and to water deficit (Table 4) was consistent with the field information (Table 1). The ranking divergence for $\mathrm{C} 12$ and $\mathrm{C} 2$ can be attributed to errors during the evaluation or unfavorable conditions to this classification at the field level. Alternatively, for example, the necessary fine-tuning of the used variables, such as the quantification of cell sizes and types composing the xylem and estimates of vascular tissue conductivity, or by using a larger sample number for estimating the variables, may all contribute the increasing the genotype-classification accuracy. Elucidating these issues is underway in ongoing experiments and are independent of the favorable outcome in using the employed variables and the feasibility of early selection advocated in this study. 
Table 4. Ranking of commercial eucalyptus genotypes based on the sum of ranks in relation to the biomarkers of stomatal density (SD), total cross-sectional area (CSAP), cross-sectional area of the vascular tissue (VTA), the xylem (XYL), phloem (PHL) and cortex (CA), total leaf thickness (TLT), stomatal conductance (gs), transpiration 60 days (E1), photosynthesis 90 days (A2) and transpiration 90 days (E2) of 12 eucalyptus clones subjected to treatments using $100 \mathrm{~mL} \mathrm{H}_{2} \mathrm{O}$ (number before the bar, in Rank column) and $300 \mathrm{mg} \mathrm{L}^{-1} \mathrm{PEG}$ (number after the bar, in Rank column) for simulating the water deficit.

\begin{tabular}{|c|c|c|c|c|c|c|c|c|c|c|c|c|c|}
\hline \multirow[b]{3}{*}{ Order } & \multirow{2}{*}{\multicolumn{8}{|c|}{ Anatomics }} & \multirow{2}{*}{\multicolumn{5}{|c|}{ Physiological }} \\
\hline & & & & & & & & & & & & & \\
\hline & Clone & $\mathrm{DE}$ & AST & ATV & XIL & FLO & $\mathrm{AC}$ & ETC & gs & E1 & A2 & E2 & $\begin{array}{l}\text { Final } \\
\text { rank }\end{array}$ \\
\hline 1 & C6-T & $6 / 1$ & $1 / 1$ & $3 / 1$ & $1 / 1$ & $2 / 2$ & $3 / 1$ & $2 / 1$ & $7 / 1$ & $5 / 1$ & $11 / 1$ & $12 / 1$ & 2.95 \\
\hline 2 & C7-T & $1 / 2$ & $2 / 3$ & $5 / 2$ & $12 / 2$ & $12 / 1$ & $10 / 9$ & $8 / 7$ & $10 / 2$ & $7 / 2$ & $10 / 2$ & $5 / 4$ & 5.36 \\
\hline 3 & C10-T & $4 / 5$ & $11 / 9$ & $12 / 3$ & $3 / 10$ & $8 / 5$ & $2 / 7$ & $1 / 4$ & $11 / 3$ & $1 / 3$ & $5 / 9$ & $1 / 6$ & 5.59 \\
\hline 4 & C9-T & $5 / 9$ & $4 / 6$ & $3 / 5$ & $9 / 7$ & $5 / 4$ & $1 / 10$ & $6 / 6$ & $2 / 5$ & $8 / 7$ & $6 / 7$ & $4 / 7$ & 5.72 \\
\hline 5 & C1-T & $3 / 6$ & $3 / 2$ & $8 / 9$ & $6 / 9$ & $7 / 3$ & $7 / 4$ & $5 / 2$ & $12 / 6$ & $2 / 9$ & $8 / 4$ & $9 / 8$ & 6.00 \\
\hline 6 & С3-T & $9 / 7$ & $5 / 5$ & $1 / 8$ & $2 / 3$ & $1 / 11$ & $6 / 8$ & $10 / 8$ & $5 / 10$ & $9 / 8$ & $9 / 3$ & $2 / 2$ & 6.01 \\
\hline 7 & C11-S & $7 / 3$ & $8 / 4$ & $9 / 6$ & $7 / 5$ & $6 / 9$ & $5 / 2$ & $4 / 9$ & $6 / 8$ & $6 / 5$ & $3 / 5$ & $7 / 9$ & 6.04 \\
\hline 8 & C5-S & $2 / 8$ & $10 / 11$ & $4 / 7$ & $4 / 11$ & $3 / 7$ & $4 / 5$ & $3 / 11$ & $4 / 7$ & $3 / 6$ & $2 / 11$ & $3 / 10$ & 6.18 \\
\hline 9 & C12-T & $11 / 4$ & $12 / 7$ & $11 / 4$ & $11 / 4$ & $9 / 6$ & $8 / 12$ & $7 / 5$ & $9 / 4$ & $10 / 4$ & $8 / 6$ & $6 / 3$ & 7.32 \\
\hline 10 & C8-S & $8 / 11$ & $7 / 8$ & $6 / 10$ & $5 / 6$ & $10 / 8$ & $11 / 3$ & $9 / 10$ & $3 / 9$ & $4 / 11$ & $1 / 8$ & $10 / 5$ & 7.41 \\
\hline 11 & C2-T & $10 / 12$ & $6 / 10$ & $7 / 12$ & $10 / 8$ & $4 / 12$ & 9/11 & $12 / 3$ & $1 / 12$ & $11 / 12$ & $4 / 10$ & $8 / 11$ & 8.86 \\
\hline 12 & C4-S & $12 / 10$ & $9 / 12$ & $10 / 11$ & $8 / 12$ & $11 / 10$ & $12 / 6$ & $11 / 12$ & $8 / 11$ & $12 / 10$ & $12 / 12$ & $11 / 12$ & 10.64 \\
\hline
\end{tabular}

Our results support the arguments of the anatomophysiological adaptations as response mechanisms to the water stress, where more favorable combinations of these characteristics are observed in the most-tolerant genotypes. Concomitantly, the evaluation of these biomarkers in young plants subjected to water stress maintains the feasibility of the early selection for characteristics of tolerance to dieback and to water deficit. This pioneering approach in using selected biomarkers based on their heritability and accuracy adds alternatives to eucalyptus breeding programs, which are then able to reduce the time spend on selection and evaluation of progenies.

Despite the reduced number of eucalyptus species, which are present in a generalized way in breeding programs, making a particular evaluation for each group of sampled genotypes is necessary, given the diversity of strategies that each species exhibit when challenged by a stress condition. This observation is equally valid when striving for individuals who are tolerant to dieback, which, as a complex etiology disorder, it also involves complexity in the strategies found in plants that lead to resistance. Indicating effective biomarkers in the discrimination of contrasting genotypes, in terms of tolerance to dieback and water deficit, opens the path for individualized-case studies to reach a better comprehension of resistance and disorder kinetics mechanisms.

\section{Conclusions}

Variables of the anatomical (stomatal density; petiole cross-sectional area; vascular tissues cross-sectional area; cortex area and total leaf thickness) and the physiological (stomatal conductance, leaf transpiration 60 and 90 days and photosynthesis 90 days) kind demonstrated medium heritability and high accuracy, thus being identified as phenotypic biomarkers for dieback and water deficit in eucalyptus.
The Mulamba \& Mock selection index enabled identifying tolerant clones from the 11 physiological-anatomical biomarkers. These biomarkers can be used for early selection of eucalyptus clones tolerant to dieback and to water stress.

\section{Acknowledgements}

This study was financed in part by the Coordenação de Aperfeiçoamento de Pessoal de Nível Superior - Brasil (CAPES) - Finance Code 001.The authors are grateful to the Suzano Papel e Celulose company, the Conselho Nacional de Desenvolvimento Científico e Tecnológico (CNPq) and the Fundação de Amparo à Pesquisa do Estado de Minas Gerais (FAPEMIG). To Federal University of Viçosa (UFV), especially the Departments of Plant Science and of Plant Biology.

\section{Literature Cited}

Alves, E. S.; Angyalossy-Alfonso, V. Ecological trends in the wood anatomy of some Brazilian species. 1. Growth rings and vessels. IAWA Journal, v. 21, n. 1, p. 3-30, 2000. https://doi. org/10.1163/22941932-90000233.

Barotto, A J.; Fernandez, M. A.; Gyenge, J.; Meyra, A.; MartinezMeier, A.; Monteoliva, S. First insights into the functional role of vasicentric tracheids and parenchyma in eucalyptus species with solitary vessels: do they contribute to xylem efficiency or safety? Tree Physiology, v.36, p. 1485-1497, 2016. https://doi. org/10.1093/treephys/tpw072.

Beltrame, R.; Bisognin, D. A.; Mattos, B. D.; Cargnelutti Filho, A.; Haselein, C. R.; Gatto, D. A.; dos Santos, G. A. Desempenho silvicultural e seleção precoce de clones de híbridos de eucalipto. Pesquisa Agropecuária Brasileira, v. 47, n. 6, p. 791796, 2012. http://seer.sct.embrapa.br/index.php/pab/article/ view/11946. 28 Jul. 2019. 
Chartzoulakis, K., Patakas, A.; Kofidis, G.; Bosabalidis, A.; Nastou, A. Water stress affects leaf anatomy, gas exchange, water relations and growth of two avocado cultivars. Scientia Horticulturae, v. 95, n. 1-2, p. 39-50, 2002. https://doi.org/10.1016/S0304-4238(02)00016-X.

Chaves, J. H.; Ferreira, M. D. G. R.; Lima, J. C. N.; Macedo, J. E. P.; Quero, H. P. Seleção precoce de clones de eucalipto para ambientes com disponibilidade diferenciada de água no solo: relações hídricas de plantas em tubetes. Revista Árvore, v. 28, n. 3, p. 333-341, 2004. https://doi.org/10.1590/S0100-67622004000300003.

Chaves, M. M.; Flexas, J.; Pinheiro, C. Photosynthesis under drought and salt stress: regulation mechanisms from whole plant to cell. Annals of Botany, v. 103, n. 4, p. 551-560, 2009. https://doi. org/10.1093/aob/mcn125.

Corrêa, T. R.; Toledo Picoli, E. A.; Souza, G. A.; Condé, S. A.; Silva, N. M.; Lopes-Mattos, K. L. B.; Oda, S. Phenotypic markers in early selection for tolerance to dieback in Eucalyptus. Industrial Crops and Products, v. 107, p. 130-138, 2017. https://doi.org/10.1016/j. indcrop.2017.05.032.

Dayer, S.; Peña, J. P.; Gindro, K.; Torregrosa, L.; Voinesco, F.; Martínez, L.; Prieto, J. A.; Zufferey, V. Changes in leaf stomatal conductance, petiole hydraulics and vessel morphology in grapevine (Vitis vinifera cV. Chasselas) under different light and irrigation regimes. Functional Plant Biology, v. 44, n. 7, p. 679-693, 2017. https://doi.org/10.1071/FP16041.

Doheny-Adams, T.; Hunt, L.; Franks, P. J.; Beerling, D. J.; Gray, J. E. Genetic manipulation of stomatal density influences stomatal size, plant growth and tolerance to restricted water supply across a growth carbon dioxide gradient. Philosophical Transactions of the Royal Society B: Biological Sciences, v. 367, n. 1588, p. 547555, 2012. https://doi.org/10.1098/rstb.2011.0272.

Ferreira, F. A. Patologia florestal: principais doenças florestais no Brasil. Viçosa: SIF, 1989. 570p.

Flexas, J.; Barbour, M. M.; Brendel, O.; Cabrera, H. M.; Carriquí, M.; Diaz-Espejo, A.; Gallé, A. Mesophyll diffusion conductance to $\mathrm{CO}_{2}$ : an unappreciated central player in photosynthesis. Plant Science, v. 193-194, p. 70-84, 2012. https://doi.org/10.1016/j. plantsci.2012.05.009.

Grisi, F. A.; Alves, J. D.; Castro, E. M.; Oliveira, C.; Biagiotti, G.; Melo, L. A.Avaliações anatômicas foliares em mudas de café 'Catuaíe 'Siriema'submetidas ao estresse hídrico. Ciência e Agrotecnologia, v. 32, n. 6, p. 1730-1736, 2008. https://doi. org/10.1590/S1413-70542008000600008.

Hamanishi, E. T.; Thomas, B. R.; Campbell, M. M. Drought induces alterations in the stomatal development program in Populus. Journal of Experimental Botany, v. 63, n. 13, p. 49594971, 2012. https://doi.org/10.1093/jxb/ers177.

$\mathrm{Hu}, \mathrm{H}$.; Chen, $\mathrm{H} ; \mathrm{Hu}, \mathrm{T}$;; Zhang, J. Adaptability comparison between the seedlings of Eucalyptus grandis and Almus cremastogyne under the condition of continuous drought stress. Journal of Agricultural Science, v. 4, n. 4, p. 75-86, 2012. https://doi.org/10.5539/jas.v4n4p75.

Huck, M. G.; Klepper, B.; Taylor, H. M. Diurnal variations in root diameter. Plant Physiology, v. 45, n. 4, p. 529, 1970. https://doi. org/10.1104/pp.45.4.529.

Jacobsen, A L.; Pratt, R. B.; Venturas, M. D.; Hacke, U. G. Large volume vessels are vulnerable to water-stress-induced embolism in stems of poplar. IAWA Journal, v. 40, n. 1, p. 4-22, 201, 2019. https://doi.org/10.1163/22941932-40190233.
Jinagool, W.; Rattanawong, R.; Sangsing, K.; Barigah, T. S.; Gay, F.; Cochard, H.; Kasemsap, P.; Herbette, S. Clonal variability for vulnerability to cavitation and other drought-related traits in Hevea brasiliensis Müll. Arg. Journal of Plant Hydraulics, v.2, e001, 2015. https://doi.org/10.20870/jph.2015.e001.

Jurskis, V. Eucalypt decline in Australia, and a general concept of tree decline and dieback. Forest Ecology and Management, v. 215, n. 1-3, p. 1-20, 2005. https://doi.org/10.1016/j.foreco.2005.04.026.

Kulkarni, M.; Deshpande, U. Comparative studies in stem anatomy and morphology in relation to drought resistance in tomato (Lycopersicon esculentum). American Journal of Plant Physiology, v. 1, n. 1, p. 82-88, 2006. https://doi.org/10.3923/ajpp.2006.82.88.

Kutlu, N.; Terzi, R.; Tekeli, Ç.; Şenel, G.; Battal, P.; Kadioğlu, A. Changes in anatomical structure and levels of endogenous phytohormones during leaf rolling in Ctenanthe setosa under drought stress. Turkish Journal of Biology, v. 33, n. 2, p. 115-122, 2009. https://doi:10.3906/biy-0806-6.

Laajimi, N. O.; Boussadia, O.; Skhiri, F. H.; Teixeira da Silva, J. A.; Rezgui, S.; Hellali, R. Anatomical adaptations in vegetative structures of apricot tree (Prunus armeniaca L.) cv.'Amor El Euch'grown under water stress. Fruit, Vegetable and Cereal Science and Biotechnology, v. 5, n. 2, special, p. 46-51, 2011. https://www. researchgate.net/publication/283623566. 28 Jul. 2019.

Larcher, W. Ecofisiologia vegetal. São Carlos: Editora RIMA, 2006. 531p. Leite, F. P.; Novais, R. F.; Silva, I. R.; Barros, N. F.; Neves, J. C. L. N.; Medeiros, A. G. B.; Ventrella, M. C.; Villani, E. M. A. Manganese accumulation and its relation to" eucalyptus shoot blight in the Vale do Rio Doce". Revista Brasileira de Ciência do Solo, v. 38, n. 1, p. 193-204, 2014. https://doi.org/10.1590/S010006832014000100019.

Mattiello, E. M.; Ruiz, H. A.; da Silva, I. R.; de Barros, N. F.; Neves, J. C. L.; Behling, M. Transporte de boro no solo e sua absorção por eucalipto. Revista Brasileira de Ciência do Solo, v. 33, n. 5, p. 1281-1290, 2009. https://doi.org/10.1590/S010006832009000500021.

Miranda, A. C.; de Moraes, M. L. T.; Tambarussi, E. V.; Furtado, E. L.; Mori, E. S.; da Silva, P. H. M.; Sebbenn, A. M. Heritability for resistance to Puccinia psidii Winter rust in Eucalyptus grandis Hill ex Maiden in Southwestern Brazil. Tree Genetics \& Genomes, v. 9, n. 2, p. 321-329, 2013. https://doi.org/10.1007/s11295-0120572-x.

Moraes, C. B. D.; de Freitas, M.; Casella, T.; Pieroni, G. B.; Vilela de Resende, M. D.; Zimbacks, L.; Mori, E. S. Estimativas de parâmetros genéticos para seleção precoce de clones de Eucalyptus para região com ocorrência de geadas. Scientia Forestalis, v. 42, n. 102, p. 219-227, 2014. https://www.ipef.br/ publicacoes/scientia/nr102/cap06.pdf. 02 Ago. 2019.

Mulamba, N. N.; Mock, J. J. Improvement of yield potential of the ETO blanco maize (Zea mays L.) population by breeding for plant traits [Mexico]. Egyptian Journal of Genetics and Cytology, v. 7, n. 1, p. 40-51, 1978.

Oliveira, A. D.; Caixeta, E.; Zambolim, E.; Zambolim, L.; Sakiyama, N. Aplicação técnica de marcadores moleculares no melhoramento de plantas. Campinas: Instituto Agronômico, 2007. 17p. (Documentos IAC, 81). http://www.iac.sp.gov.br/publicacoes/ publicacoes_online/pdf/doc81.pdf. 28 Jul. 2019. 
Otto, M. S. G.; Vergani, A. R.; Gonçalves, A. N.; Vrechi, A.; Silva, S. R.; Stape, J. L. Fotossíntese, condutância estomática e produtividade de clones de Eucalyptus sob diferentes condições edafoclimáticas. Revista Árvore, v. 37, n. 3, p. 431-439, 2013. https://doi.org/10.1590/S0100-67622013000300006.

Resende, M. D. V. Software Selegen-REML/BLUP: a useful tool for plant breeding. Crop Breeding and Applied Biotechnology, v. 16 , n. 4 , p. $330-339$, 2016. https://doi.org/10.1590/1984$70332016 \mathrm{v} 16 \mathrm{n} 4 \mathrm{a} 49$.

Resende, M. D. V.; Duarte, J. B. Precisão e controle de qualidade em experimentos de avaliação de cultivares. Pesquisa Agropecuária Tropical, v. 37, n.3, p. 182-194, 2007. https://www.revistas.ufg. br/pat/article/download/1867/1773. 10 Jul. 2019.

Resende, M. D. V; Barbosa, M. H. P. Melhoramento genético de plantas de propagação assexuada. Colombo: Embrapa Informação Tecnológica, 2005. 130p.

Resende, M. D.V. Genética biométrica e estatística no melhoramento de plantas perenes. Brasília: Embrapa Informação Tecnológica, 2002. $975 p$.
Sala, A.; Piper, F.; Hoch, G. Physiological mechanisms of droughtinduced tree mortality are far from being resolved. New Phytologist, v. 186, n. 2, p. 274-281, 2010. https://doi. org/10.1111/j.1469-8137.2009.03167.x.

Segatto, F. B.; Bisognin, D. A.; Benedetti, M.; Costa, L. C. D.; Rampelotto, M. V.; Nicoloso, F. T. Técnica para o estudo da anatomia da epiderme foliar de batata. Ciência Rural, v. 34, n. 5, p. 1597-1601, 2004. https://doi.org/10.1590/S0103-84782004000500042.

Silva, E. C.; Nogueira, R. J.; Vale, F. H.; Araújo, F. P. D.; Pimenta, M. A. Stomatal changes induced by intermittent drought in four umbu tree genotypes. Brazilian Journal of Plant Physiology, v. 21 , n. 1 , p. $33-42$, 2009. https://doi.org/10.1590/S167704202009000100005.

Taiz, L.; Zeiger, E. Fisiologia vegetal. 5.ed. Porto Alegre: Artmed, 2013. $954 p$.

Tatagiba, S. D.; Pezzopane, J. E. M.; dos Reis, E. F.; Penchel, R. M. Desempenho de clones de eucalipto em resposta a disponibilidade de água no substrato. Revista Engenharia na Agricultura, v. 17, n. 3 , p.179-189, 2009. https://doi.org/10.13083/1414-3984.v17n03a02. 